\title{
Chloroquine as Reposition Drugs for Novel Coronavirus SARS-COV-2 Emergence
}

\section{Indranil Chatterjee ${ }^{1 *}$ and Manas Chakraborty*2}

${ }^{1}$ Assistant Professor, Department of Microbiology, Birbhum Pharmacy School, Birbhum, West Bengal, India

${ }^{2}$ Professor, Department of Pharmaceutical Biotechnology, Calcutta Institute of Pharmaceutical Technology and Allied Health Sciences, Howrah, West Bengal, India

*Corresponding Author: Indranil Chatterjee, Assistant Professor, Department of Microbiology, Birbhum Pharmacy School, Birbhum, West Bengal, India and Manas Chakraborty Professor, Department of Pharmaceutical Biotechnology, Calcutta Institute of Pharmaceutical Technology and Allied Health Sciences, Howrah, West Bengal, India.

ORCiD ID: Indranil Chatterjee: https://orcid.org/0000-0003-3366-819X

Manas Chakraborty: https://orcid.org/0000-0001-7521-0617

A movement to reposition tablets has been initiated in current years [1]. In this strategy, it is vital to use tablets which have been tested to be harmless and whose pharmacokinetics and most advantageous dosage are well known. In the current episode of novel coronavirus (SARS-CoV-2) emergence [2], we find a wonderful exenough of possible repositioning of tablets, especially chloroquine. We had 20 years ago proposed to systematically check chloroquine in viral infections as it have been proven to be powerful in vitro against a broad variety of viruses $[3,4]$. This drug has more than one activity, one among that's to alkalise the phagolysosome, which hampers the low-pH-based steps of viral replication, along with fusion and uncoating [4]. Other mechanisms of antiviral hobby are poorly explained [5]. At the time of the extreme acute breathing syndrome (SARS)-associated coronavirus epidemic [6] in 2003, several molecules have been tested to assess their effectiveness towards this virus. Among these, teicoplanin [7], an antistaphylococcal agent, had established efficacy in vitro and this changed into additionally the case for chloroquine, at a 50 effective concentration (EC 50) of approximatively eight $\mu \mathrm{M}$ and when introduced to the cell tradition either earlier than or after exposure to the virus [5,8-10]. These findings ended up being forgotten because of the disappearance of SARS for reasons that are neither clear nor explained [11]. The novel coronavirus presently isolated in China has been, with mind-blowing speed, evaluated concerning its sensitivity to already used capsules [12]. Thus, the brand-new antiviral drug remdesivir [13] in addition to chloroquine, at an EC 50 of $1.1 \mu \mathrm{M}$, have been discovered to be powerful in preventing replication of this virus [12]. Chloroquine is perhaps one of the most prescription drugs within the world $[14,15]$. As a count number of facts, all Europeans touring malaria-endemic geographic areas for many years received chloroquine prophylaxis and persevered it for two months after their return. In addition, local citizens took chloroquine continuously, and treatment of malaria has long been based in this drug. In addition, hydroxychloroquine has been used for decades at much better doses (up to $600 \mathrm{mg} /$ day) to deal with autoimmune diseases [16]. It is difficult to find a product that presently has a better-established protection profile than chloroquine. Furthermore, its price is negligible. Hence, its viable use each in prophylaxis in people exposed to the unconventional coronavirus and as a curative remedy will probably be right away evaluated by means of our Chinese colleagues. If clinical records verify the biological results, the unconventional coronavirus-associated sickness will have end up one of the simplest and most inexpensive to deal with and prevent among infectious breathing disease.

\section{Bibliography}

1. Mullard A. "Drug repurposing programmes get lift off". Nature Reviews Drug Discovery 11.7 (2012): 505-506.

2. Zhou P., et al. "A pneumonia out- break associated with a new coronavirus of probable bat origin". Nature 579.7798 (2020): 270-273.

3. Savarino A., et al. "New insights into the antiviral effects of chloroquine". Lancet Infectious Diseases 6.2 (2006): 67-69.

4. Rolain JM., et al. "Recycling of chloroquine and its hydroxyl analogue to face bacterial, fungal and viral infections in the $21^{\text {st }}$ century". International Journal of Antimicrobial Agents 30.4 (2007): 297-308.

5. Vincent MJ., et al. "Chloroquine is a potent inhibitor of SARS coronavirus infection and spread". Virology Journal 2 (2005): 69. 
6. Ksiazek TG., et al. "A novel coronavirus associated with severe acute respiratory syndrome". New England Journal of Medicine 348.20 (2003): 1953-1966.

7. Balzarini J., et al. "Inhibition of feline (FIPV) and human (SARS) coronavirus by semisynthetic derivatives of glycopeptide antibiotics". Antiviral Research 72.1 (2006): 20-33.

8. Keyaerts E., et al. "In vitro inhibition of severe acute respiratory syndrome coronavirus by chloroquine". Biochemical and Biophysical Research Communications 323 (2004): 264-268.

9. Barnard DL., et al. "Evaluation of immunomodulators, interferons and known in vitro SARS-coV inhibitors for inhibition of SARS-coV replication in BALB/c mice". Antiviral Chemistry and Chemotherapy 17 (2006): 275-284.

10. de Wilde AH., et al. "Screening of an FDA-approved compound library identifies four small-molecule inhibitors of Middle East respiratory syndrome coronavirus replication in cell culture". Antimicrobial Agents and Chemotherapy 58.8 (2014): 4875-4884.

11. Yu IT., et al. "Severe acute respiratory syndrome beyond Amoy Gardens: completing the incomplete legacy". Clinical Infectious Diseases 58.5 (2014): 683-686.

12. Wang M., et al. "Remdesivir and chloroquine effectively inhibit the recently emerged novel coronavirus (2019-nCoV) in vitro". Cell Research 30.3 (2020): 269-271.

13. Agostini ML., et al. "Coronavirus susceptibility to the antiviral remdesivir (GS-5734) is mediated by the viral polymerase and the proofreading exoribonuclease". mBio 9.2 (2018): e00221-18.

14. White NJ., et al. "Malaria”. Lancet 383.9918 (2014): 723-735.

15. Al-Bari MA. "Chloroquine analogues in drug discovery: new directions of uses, mechanisms of actions and toxic manifestations from malaria to multifarious diseases". Journal of Antimicrobial Chemotherapy 70 (2015): 1608-1621.

16. Lee SJ., et al. "The role of antimalarial agents in the treatment of SLE and lupus nephritis". Nature Reviews Nephrology 7.12 (2011): 718-729.

\section{Assets from publication with us}

- Prompt Acknowledgement after receiving the article

- Thorough Double blinded peer review

- Rapid Publication

- Issue of Publication Certificate

- High visibility of your Published work

Website: https://www.actascientific.com/

Submit Article: https://www.actascientific.com/submission.php Email us: editor@actascientific.com

Contact us: +919182824667 